\section{Reorganized Family Planning}

SIR,-Your leading article (22 December, $p$ 690) reporting a symposium held at Southampton quotes the reasonable suggestion that "hospital clinics should deal with the problem cases" and then goes on quite unreasonably to include in this group "women after delivery." I suspect a slip of the pen; "women after termination" perhaps, bu after normal confinement surely not.

It was good to read that there was agreement that the general practitioner should have the major responsibility for advice and supplies. At the moment many local authorities are providing both without charge to the patient and many family doctors realize that they would be placing their patients at an economic disadvantage if they were to look after them themselves. Even prescription on EC10 in cases of medical need costs the patient 20p more than the free supplies from the clinic and precludes the G.P. from earning anything extra for his service. The new generation of I.U.D.s are not available on EC10 anyway. The present system has led to ridiculous anomalies even within one practice area. My patients living in Lewisham or Lambeth may receive supplies, including I.U.D.s, "free" (that is, at the ratepayers' expense) whether they attend my surgery or the clinic. My patients living in Southwark and Croydon may receive them "free" only if they attend the clinic.

Reorganization of the family planning service should have as its primary aim the integration into it of the family doctor, which means enabling him to provide contraceptive advice and supplies and receive payment on the same terms as the clinics. After his integration will be the proper time to assess patient preferences with regard to clinics or doctors' surgeries, and to assess any deficit (which I for one do not acknowledge) in the contraceptive training of G.P.s.-I am, etc.,

London S.E.15

LESLIE OLDERSHAW

\section{Regrouping of Designated Areas}

SIR,-By the fortuitous accident of having our senior partner on the "shadow" local medicine committee of the new Salford area, my partners and I have just discovered a nation-wide plot to deprive large numbers of doctors practising in designated areas of their payments for practising therein. This is to be carried out by regrouping the practice areas and, on paper, diluting the under-doctored areas by amalgamation with nearby (relatively) over-doctored areas, thus reducing the average list size to under the arbitrary 2,500 level at which designated area payments are usually made. This will, at a stroke, deprive all doctors in the affected areas of at least $£ 500$ per annum without reducing their work load by one patient.

This is, to borrow a phrase from our much publicized trade unionist, "a diabolical liberty" and must be resisted from the outset by every doctor wherever he practises. I would be grateful if you could give this matter full publicity through your columns and urge all doctors, whether affected or not by any such schemes, to unite in condemnation of such underhand, cheese-paring methods of dealing with us. This is a major issue and must be pursued with all vigour, accompanied if necessary by the resignation of every doctor practising in any sphere of the N.H.S., because it is obvious that the Government has no respect for any group of workers who are prepared to allow themselves to be "negotiat $\epsilon$ " out of their jus dues as we were in 1966, 1968, and even las year. Bitter experience should have taught even the mildest of us that it is only by presenting a united front, backed if necessary by our resignations, that anything can be achieved. Furthermore, if it should be necessary to submit our resignations, then it is imperative that they should not be withdrawn until everything which we have asked for has been granted and not merely promised.- I am, etc.

Irlam, Manchester

\section{J. DERBYSHIRE}

SIR,-I feel that the attention of your readers should be drawn once more to the self-effacing, generous action of general practitioners working in designated areas who are being asked to give up part of their in come in order to finance the N.H.S. reorganization.

Because of boundary reorganization designated areas are being grouped with nondesignated areas, thus on paper lowering the average size of list within the designated area. In practice the G.P.s will have no fewer patients but they will not receive the payment due for lists of types I and II designation. Yet again we are subsidizing a creaking N.H.S.

May I appeal to all members of the medical profession to support the stand that those G.P.s affected will be making against bureaucratic robbery? - I am, etc.

\section{Swinton,}

R. H. DavenporT

Manchester

\section{Fees for Dental Anaesthetics}

SIR,-With reference to your medicolegal report (2 February, p. 207) the coroner for Waltham Forest is to be congratulated for asking when the requirements of the 1967 report on dental anaesthesia ${ }^{1}$ are going to be properly implemented. The report states that ideally dental anaesthetics should be given by "specialist anaesthetists." It goes on to say that this ideal will be unattainable for some years to come. Six years have come and gone with little evident progress. That so few consultant anaesthetists are prepared to work with general dental praotitioners in the Health Service is probably because of the inequitable system of payment. The usual fee is less than onesixth of that for a domiciliary visit. Unlike the domiciliary visitor, the dental anaesthetist does not get extra payments towards the cost of his car, drugs, and anaesthetic appanatus. Nor does he enjoy an addition to his pension like that which is derived from domiciliary visit fees. These anomalies continue because the Department of Health and Social Security insists on classifying the dental anaesthetic as an item of dental service, the gross fee for which is determined by the Dental Rates Study Group. The scale of fees which results is designed to be appropriate for general dental practitioners. The consultant's fee should not be arrived at like this, but should be the subject of a recommendation by the Review Body in common with other items of consultant remuneration.

Most patients needing dental anaesthesia are young, in otherwise good general health, and suffering from non-lethal conditions. They deserve exper.enced anaesthetists. I hope that the tragedy your legal correspondent described may hasten the reforms needed to ensure that they get them.-I am, etc.,

Department of Anaesthetics,

Philip James

Isle of Wight Hospital Group,

Ministry of Health, Central Health Service Council, Dental Anaesthesia. Report of a foint Sub-Committee of the Standing Medical and Dental Advisory.

\section{Consultant Discontent}

SIR,-I would fully endorse the opinion expressed in your leading article "Think Again" (9 February, p. 211). Consultants in both the teaching and regional hospitals must fight together for better conditions and pay. Unity must be seen to be present.

The leading article left many things unsaid. In the opinion of most consultants the B.M.A. is a general practitioner organization and anything that is not entirely in the G.P.s' interest does not get full support. I was on the Central Committee for Hospital Medical Services at the time the G.P.s negotiated their new charter. We were asked, albeit by our own leaders, to support this and not to press our own claims at that particular time. In other words the claim was supported by the whole profession. I have failed to see evidence of similar support for our claims by our G.P. colleagues or indeed by the B.M.A. as a whole. The leading article quotes a typical example of the General Medical Services Committee negotiating a new contract for G.P. interests alone for the family planning services. There can be no justification for the B.M.A. accepting this. A further recent example is their acceptance of the petrol rationing scheme.

It is Dr. Stevenson's proud boast that one of the main achievements of the first 25 years of the N.H.S. has been the increased status of the G.P.s, but he fails to note that only half his task has been achieved. I believe that Dr. Stevenson's recent letter to the profession castigating the Regional Hospitals' Consultants and Specialists Association should never have been written. This was not a call for unity.

I joined the B.M.A. over 30 years ago and have always supported the C.C.H.M.S. in its difficult and thankless task. I would like to go on doing so. I joined the R.H.C.S.A. 27 years ago because I believed (I still do) that it supplemented rather than opposed the B.M.A. Its virility and militancy should be seen as an asset by our negotiators. Its present action has been brought about by its failure to achieve recognition by or cooperation with the C.C.H.M.S. Both R.H.C.S.A. and C.C.H.M.S. have the same aims and objects and they have a large common membership. Both should be big enough to sink their differences, and I would have no doubt that their members would wish them to do so. 'The responsibility for failure must rest with their leaders. Neither the B.M.A. itself nor its constitution should be allowed to prevent agreement. 